\title{
Anaerobic treatment of residuals from tanks transporting food and fodder
}

\author{
Van Than Nguyen $^{1,2}$ (D) Erik Beyer ${ }^{2} \cdot$ Jan Neumann $^{3} \cdot$ Dirk Awe $^{4} \cdot$ Wolfgang Pfeiffer $^{2} \cdot$ Jens $^{\text {Tränckner }}{ }^{1}$
}

Received: 25 July 2018 / Accepted: 27 November 2018 / Published online: 13 December 2018

(C) The Author(s) 2018

\begin{abstract}
The anaerobic digestion of wastewater from the cleaning of tank cars transporting food and fodder was investigated in both bench and pilot scales with a single-stage, mesophilic $\left(39^{\circ} \mathrm{C}\right)$, completely mixed process. The promising results lead to the planning and building of a $1200-\mathrm{m}^{3}$ full-scale biogas plant at TS-Clean cleaning station in Fahrbinde, Germany. Due to softened water used in the cleaning of the car tanks, the alkalinity in the digester decreased as predicted by the physicochemical model developed for this treatment process. The model showed that $2.4 \mathrm{~kg} \mathrm{NaHCO} / \mathrm{m}^{3}$ of wastewater has to be added in order to control digester $\mathrm{pH}$ at 7.2 and to maintain the digester alkalinity at $3.1 \mathrm{~g} \mathrm{CaCO}_{3} / \mathrm{L}$. In a laboratory study, the decrease of alkalinity caused a volatile organic acids accumulation and $\mathrm{pH}$ drop below the optimal range. In this case, if chemical buffering was not added into the digester, the digester deteriorated. In a 3-year investigation, we confirmed that the strongly polluted WW from the cleaning of tank cars transporting food and fodder is suitable for an anaerobic treatment if the organic loading rate is controlled below $4 \mathrm{~kg} \mathrm{COD} / \mathrm{m}^{3} /$ day, digester alkalinity is adjusted by $\mathrm{NaHCO}_{3}$, and micronutrients are added despite constant considerable variations in strength and composition of the wastewater. A biogas yield of $35-45 \mathrm{~m}^{3} \mathrm{CH}_{4} / \mathrm{m}^{3}$ of wastewater and a COD elimination of 80-90\% were achieved in bench- and pilot-scale experiments and are achieved in the full-scale biogas plant. The full-scale biogas plant is working stable with a biogas yield of $68 \mathrm{~m}^{3}$ biogas $/ \mathrm{m}^{3}$ of wastewater.
\end{abstract}

Keywords Wastewater from the cleaning of tank cars transporting food and fodder · Anaerobic treatment · Biogas plant . Physiochemical model of anaerobic digestion

\section{Introduction}

Food and fodder like chocolate, cacao, sugar, milk, fruit juice, starch, different types of oils, and glycerol in the form of liquid, paste, or powder are transported in tank cars. The tanks

Responsible editor: Gerald Thouand

Van Than Nguyen

van.nguyen2@uni-rostock.de

1 Faculty of Agricultural and Environmental Sciences, University of Rostock, Justus-von-Liebig-Weg 6, 18059 Rostock, Germany

2 Department of Mechanical/Process and Environmental Engineering, University of Wismar, Philipp-Müller-Straße 14,

23966 Wismar, Germany

3 TS-Clean Tank- und Siloreinigung Neumann GmbH, Ahorn Straße 9, 19288 Fahrbinde, Germany

4 Rotaria Energie und Umwelttechnik GmbH, Kirchweg 21, 18230 Rerik, Germany require regular cleaning and disinfection. In Europe, about 300,000 tons of food and fodder are transported daily by tank cars. About 40,000-50,000 food and fodder transport containers are cleaned and disinfected daily in approximately 1600 cleaning stations (Philipowski 2016). Germany has some 100 cleaning stations.

The cleaning process consists in case of a strong pollution of the tanks in mechanical removal of remains and/or precleaning with $160{ }^{\circ} \mathrm{C}$ steam. All tanks are cleaned with $85^{\circ} \mathrm{C}$ hot soapy water and are finally rinsed with water. In all cleaning processes, softened water is used. Pre-cleaning and washing of considerably polluted tanks generate strongly polluted wastewater. Washing of only moderately polluted tanks and rinsing generates moderately polluted wastewater. The strongly and the moderately polluted wastewater (WW) is mostly not collected separately and are often discharged to the communal wastewater treatment plant (WWTP) without any pre-treatment. Sometimes, however, the wastewater is pretreated in order to meet the standards for indirect discharge. Pre-treatment processes applied are mostly mechanical 
processes like flocculation/sedimentation and/or aerobic biological treatment processes (Philipowski 2008; Rudolph et al. 1995; Röhr and Müßig 2006).

TS-Clean company is operating three cleaning stations in Germany cleaning tank cars transporting food and fodder. At TS-Clean sites, strongly polluted WW is collected separately and discharged into an equalization tank. At Fahrbinde site, weekly, $35 \mathrm{~m}^{3}$ of strongly polluted WW for the cleaning of some 200 tank cars was transported to a biogas plant and later to a WWTP for co-digestion. The moderately polluted WW is discharged through a grease trap to the municipal WWTP. TSClean company had the idea to treat the strongly polluted WW from all three sites in Fahrbinde in order to produce biogas substituting natural gas used in the steam generator and thus reducing costs for natural gas and the wastewater disposal. The schemes of the old and the new concept for the WW treatment processes are shown in Fig. 1.

In the relevant technical literature, no information on the anaerobic digestion of WW from the cleaning of tank cars could be found. Due to that reason, the anaerobic digestion of this WW was investigated in bench- $(3 \mathrm{~L})$ and pilot-scale $(500 \mathrm{~L})$, before a full-scale digester was planned and built in Fahrbinde. In the investigation, the digester effluent was flocculated and filtrated and the filtrate treated in a sequencing batch reactor in order to confirm that a stable aerobic posttreatment meeting the direct discharge standards of the effluent of the anaerobic treatment is possible.

Preliminary experiments showed that the anaerobic digester operated well for a long time; however, the biogas production and chemical oxygen demand (COD) removal efficiency suddenly dropped after some 100 days of operation and the digester failed (data not shown). The sudden failure after such a long time of operation was considered to be the result of the softened water used in the cleaning, the deficiency of trace metals, maybe in combination with organic overloading, and insufficient alkalinity.

Relevant technical literature, reports that micro- and macronutrients play an important role for the growth, chemical reactions, and enzyme activity in the anaerobic digestion process (Choong et al. 2016; Mao et al. 2015). Recently, many researchers have reported deficits of micronutrients in anaerobic digesters treating food waste or energy crops with negative effects on biogas production and process stability. In digesters using sludge or manure as a substrate, trace elements however are present in abundant concentrations (Facchin et al. 2013; Schattauer et al. 2011). Food or similar waste is often found to be low in some metal ions; that can cause the anaerobic digester to fail. Among the trace elements $(\mathrm{Co}, \mathrm{Mo}, \mathrm{Ni}, \mathrm{Fe})$, Fe was identified as most effective for stabilizing anaerobic digesters (Zhang and Jahng 2012). The results also confirmed that supplemented trace metals enhance the biogas production and process stability of anaerobic digesters. With trace elements added, organic acids remained at low concentration, and $\mathrm{pH}$ maintained stable. For this reason, trace metal concentrations were monitored in our study in order to avoid safely trace metal deficits. In our study, micronutrients from ISF-SchaumannBioenergy were dosed as done in energy crop biogas plants.

Organic loading rate (OLR) is an important parameter in the anaerobic digestion process for COD removal efficiency and process stability. In technical literature, OLR in anaerobic digestion is reported in a wide range from 1 to $19 \mathrm{~kg} \mathrm{COD} / \mathrm{m}^{3} /$ day (Jang et al. 2013; Jeganathan et al. 2006; Nagao et al.
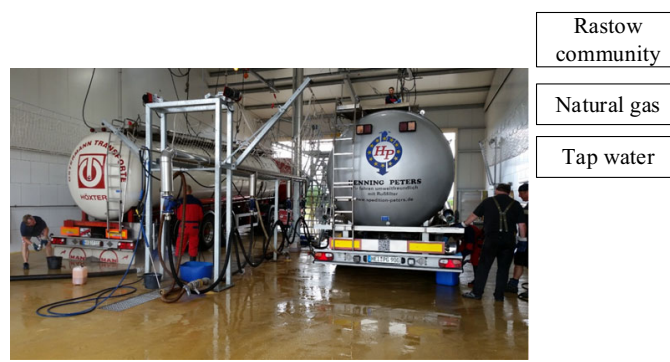

(a) $1^{\text {st }}$ phase cleaning
$\left(160^{\circ} \mathrm{C}, 80^{\circ} \mathrm{C}\right)$ $7 \mathrm{~m}^{3} / \mathrm{d}$

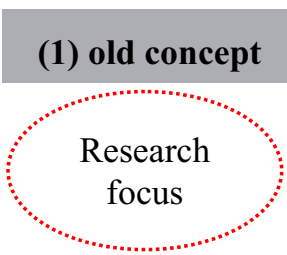

(2) new concept

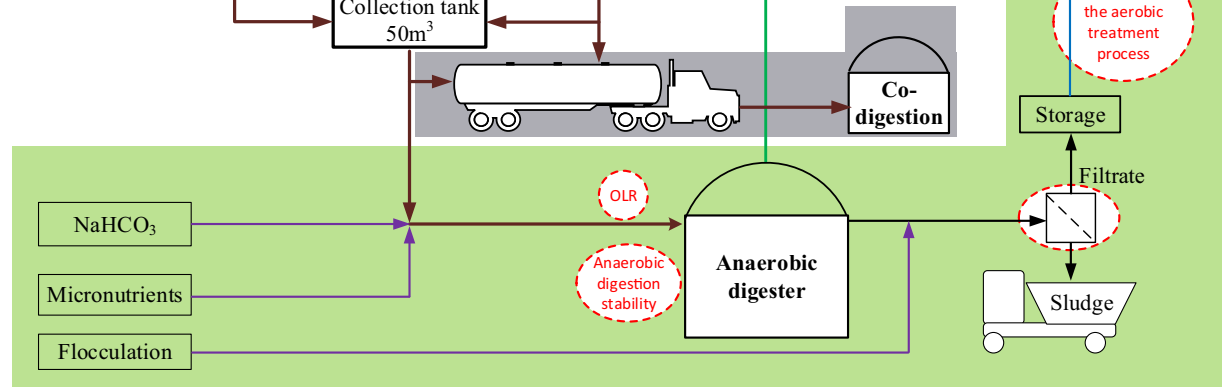

Fig. 1 Cleaning lanes (a), scheme of old (1) and new (2) concept for the WW treatment at TS-Clean plant in Fahrbinde 
2012). In a single-stage continuous digestion process, the OLR is typically in the range of $1.6-7.29 \mathrm{~kg} \mathrm{COD} / \mathrm{m}^{3} /$ day. A too high OLR or a too dramatic increase in OLR can provoke an accumulation of volatile fatty acids (VFA) (Kleyböcker et al. 2012; Li et al. 2014). This imbalance of the digestion process can eventually cause a digester deterioration. In order to avoid imbalances and failures of the digestion process, the OLR has to be controlled to be below $3 \mathrm{~kg}$ $\mathrm{COD} / \mathrm{m}^{3} /$ day for anaerobic digestion of food waste (Xu et al. 2018). In our case, due to the highly polluted WW from the cleaning of tank cars transporting food and fodder varying constantly considerably in strength and composition, OLR control needs to be focused on.

In addition, due to softened water used in the cleaning of the tank cars, insufficient alkalinity, which might cause a digestion process imbalance, was studied with a physicochemical model in order investigate the necessity of an addition of $\mathrm{NaHCO}_{3}$. Relevant technical literature confirmed that addition of buffering chemicals like $\mathrm{NaHCO}_{3}, \mathrm{Na}_{2} \mathrm{CO}_{3}$, and $\mathrm{NaOH}$ or others like lime mud can enhance the digestion performance of food waste, synthetic wastewater, and kitchen waste (Chen et al. 2015; Gao et al. 2015; Silva et al. 2015; Zhang et al. 2014). In an agricultural biogas plant in Germany, the addition of sodium bicarbonate was used to control the $\mathrm{pH}$ and to stabilize the biological process resulting in an increased yield of methane (Burgstaler et al. 2011). In our study, the effect of an addition of $\mathrm{NaHCO}_{3}$ on the stability of the digestion process was also focused on.

In the WW-laboratory of the University of Wismar in cooperation with the University of Rostock, an anaerobic preand aerobic post-treatment process of the strongly polluted WW was investigated in bench and pilot scales. The purpose of the investigation was to find out if the anaerobic treatment process was stable in spite of WW continuously varying in strength and composition and if the effluent of the treatment would fulfill indirect discharge standards and be susceptible to aerobic post-treatment fulfilling direct discharge standards. In this paper, we are focusing on the anaerobic treatment of the highly polluted WW from the cleaning of tank cars transporting food and fodder. The anaerobic digestion process was conducted in a single-stage, mesophilic, and completely mixed process. In order to maintain the digestion process stable, the effect of OLR and the addition of $\mathrm{NaHCO}_{3}$ were investigated. On the basis of the promising results of the experiments, a full-scale anaerobic treatment plant was built at the tank car cleaning station of TS-Clean in Fahrbinde.

\section{Materials and methods}

\section{Anaerobic digestion model}

Due to the softened water used in the cleaning of the tank cars, it was anticipated that a deficit in buffer capacity might be a problem for the anaerobic treatment. Therefore, a physicochemical model for the steady-state anaerobic digestion of this WW was developed in order to show the relation of $\mathrm{pH}$ and total inorganic carbon (TIC). The model also demonstrates the interrelationship of the parameters $\mathrm{pH}$, volatile organic acids (VOA), TIC, biogas production, and biogas composition. It helps the operator to control the process, to recognize beginning process imbalances, and to calculate the requirement of $\mathrm{NaHCO}_{3}$ addition for maintaining the $\mathrm{pH}$ and the process stable. The physicochemical model is based on the $\mathrm{CO}_{2} \mathrm{ab}-$ sorption equilibrium (Henry's law) and the chemical equilibrium for ammonia, carbonic, and phosphoric acid and the balance of the ion charges. The alkalinity equation was adapted from Rittmann and McCarty (2012).

Figure 2 shows the physicochemical model and the results of the model calculations for the relationship of digester $\mathrm{pH}$ and alkalinity for normal $\mathrm{CO}_{2}$ concentrations in the biogas of $30-35 \%$. The ion concentrations used in the model calculations are based on three independent measurements of the digestate performed for safeguarding sufficient concentrations of micronutrients. In order to maintain the digester $\mathrm{pH}=7.2$ 7.3 , the alkalinity has to be in the range of $3.0-4.0 \mathrm{~g} \mathrm{CaCO}_{3} / \mathrm{L}$. At low alkalinity, the digester $\mathrm{pH}$ can drop below 7.0. The alkalinity recommended for a stable digestion process is in the range of $1.5-5 \mathrm{~g} \mathrm{CaCO}_{3} / \mathrm{L}$. An alkalinity $>5 \mathrm{~g} \mathrm{CaCO}_{3} / \mathrm{L}$ makes the digester $\mathrm{pH}$ insensitive to increasing VOA concentrations (Rittmann and McCarty 2012). An excessive alkalinity is therefore generating increasing operation costs without any benefit. The model results show that the addition of $\mathrm{NaHCO}_{3}$ is crucial for maintaining the digester $\mathrm{pH}$ in the optimal range. With no addition of $\mathrm{NaHCO}_{3}$, digester $\mathrm{pH}$ shall fall to even below 6.9 . Based on the simulation, $2.4 \mathrm{~kg}$ $\mathrm{NaHCO}_{3} / \mathrm{m}^{3} \mathrm{WW}$ has to be added in order to maintain digester $\mathrm{pH}$ at 7.2.

\section{Wastewater, seeding sludge, micronutrients, buffering chemicals}

The highly polluted WW from the cleaning of tank cars transporting food and fodder is separately collected at TSClean plant Fahrbinde in a tank for a period of 1 week and is equalized and a 30- to 200-L sample was transported to our laboratory weekly. The WW chiefly contains fat (rape oil, palm oil, and cooking oil), protein (milk), carbohydrates (glucose, chocolate, fruit juice), and glycerol. The percentage of fats, carbohydrates, proteins, glycerol, and yeast is calculated based on the number of trucks, which are cleaned with the respective loads considering the degree of pollution according to the impression of the cleaner with factors of 1,2 , and 3 for slight, moderate, and strong pollution of the tanks. The analysis of some 100 different WWs in 2 years showed that the WW is complex, is highly polluted, and varies considerably in composition. The COD is in the range of 32-243 g/L. Due to 

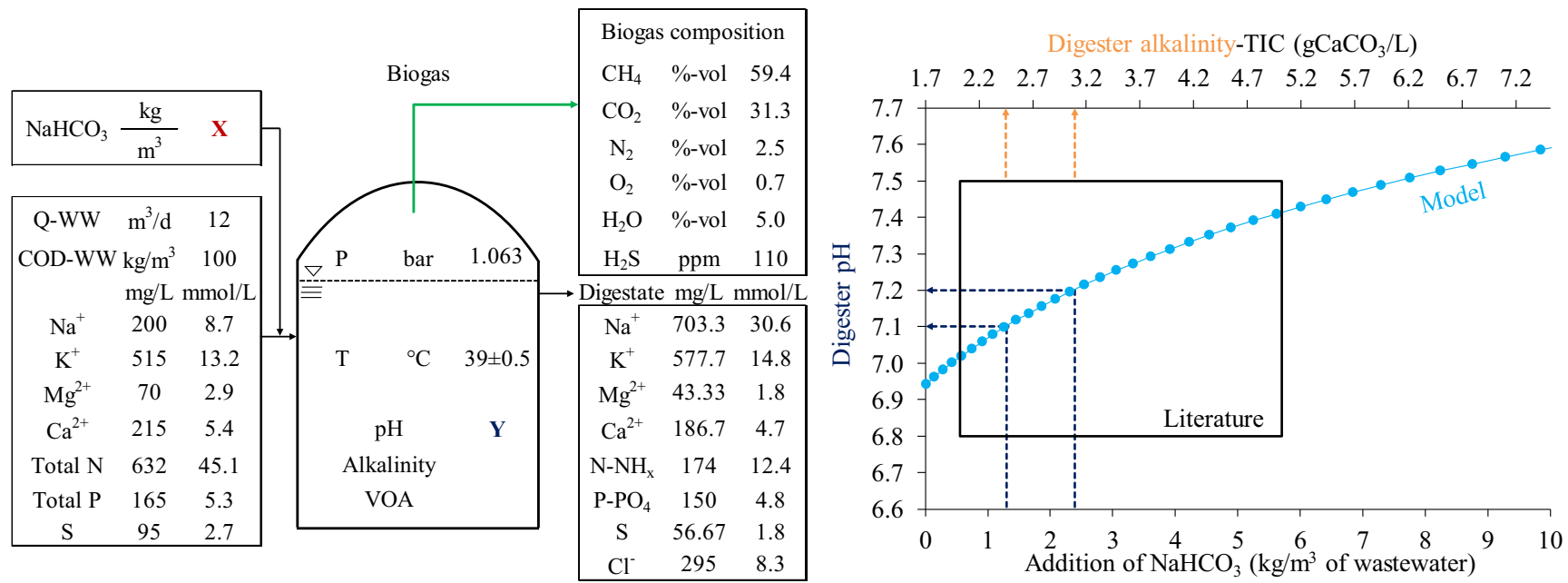

Fig. 2 Steady-state physicochemical model for anaerobic treatment of strongly polluted WW

the rapid acidification of the highly polluted $\mathrm{WW}$, the $\mathrm{pH}$ is $<$ 5. Corresponding to the number of trucks with loads rich in lipids (46\%), the WW has an average COD/VS ratio of 2.2. The characteristic of the WW is shown in Table 1.

The inoculum used for our research was taken from the pressure side of the recycle sludge pump of the $3.600 \mathrm{~m}^{3}$ mesophilic anaerobic sewage sludge digester of the WWTP Wismar, Germany. For the bench-scale experiments, an inoculum volume of $1.6 \mathrm{~L}$ sludge was used. The sludge stayed in a water bath at $39 \pm 1{ }^{\circ} \mathrm{C} 3$ to 4 days for degassing before the WW was added. In pilot-scale experiments, the digesters were filled completely with digested sewage sludge.

Micronutrients were added to the anaerobic digesters in order to compensate any deficit of trace metals of the

Table 1 The characteristic of the wastewater (mixtures of 1 week)

\begin{tabular}{llll}
\hline Parameter & Average & Ranges & Unit \\
\hline $\mathrm{pH}$ & 3.34 & $2.98-4.48$ & - \\
$\mathrm{COD}$ & 96.50 & $31-243$ & $\mathrm{~g} / \mathrm{L}$ \\
Total solids (TS) & 4.56 & $1.4-11.2$ & $\%$ \\
Volatile solids (VS) & 4.33 & $1.3-10.8$ & $\%$ \\
Total Nitrogen & 632 & $340-1000$ & $\mathrm{mg} / \mathrm{L}$ \\
Total Phosphor & 165 & $130-200$ & $\mathrm{mg} / \mathrm{L}$ \\
Fats & 46.1 & $21.1-58.1$ & $\%$ \\
Proteins & 7.6 & $1.6-22.8$ & $\%$ \\
Carbohydrates & 30.3 & $19-44$ & $\%$ \\
Yeast & 5.8 & $0-16$ & $\%$ \\
$\mathrm{Glycerol}^{2}$ & 6.1 & $0-16$ & $\%$ \\
Others* & 3.9 & $0-11$ & $\%$ \\
$\mathrm{Ca}^{2+}$ & 0.215 & $0.20-0.23$ & $\mathrm{~g} / \mathrm{L}$ \\
$\mathrm{Mg}^{2+}$ & 0.07 & & $\mathrm{~g} / \mathrm{L}$ \\
$\mathrm{K}^{+}$ & 0.515 & $0.49-0.54$ & $\mathrm{~g} / \mathrm{L}$ \\
$\mathrm{Na}^{+}$ & 0.20 & $0.18-0.22$ & $\mathrm{~g} / \mathrm{L}$ \\
\hline
\end{tabular}

*mainly coffee and salt wastewater. The nutrients and micronutrients were supplied by ISF-Schaumann-Bioenergy, Germany. The nutrient solution was added to the anaerobic digester corresponding to the COD load $(0.19 \mathrm{~g} / \mathrm{kg}$ COD of WW) as suggested by ISF-Schaumann-Bioenergy. The solution contained the trace elements copper $(\mathrm{Cu})$, nickel $(\mathrm{Ni})$, zinc $(\mathrm{Zn})$, iron $(\mathrm{Fe})$, boron (Bo), cobalt (Co), manganese (Mn), molybdenum (Mo), selenium (Se), and tungsten (W). Sodium hydrogen carbonate $\left(\mathrm{NaHCO}_{3}\right)$ was added in order to stabilize the buffer capacity of the anaerobic digestion.

\section{Anaerobic digestion experiments set-up and procedures}

The anaerobic digestion of the highly polluted WW from the cleaning of tank cars transporting food and fodder was investigated in bench- (3-L total volume) and pilot-scale (500-L total volume) single-stage, mesophilic, intermittent (bench scale), and completely (pilot scale) mixed reactors.

\section{Bench-scale digesters}

Four glass digesters (B9, B10, B11, B12) with a working volume of $1.6 \mathrm{~L}$ were operated at $39 \pm 1{ }^{\circ} \mathrm{C}$. Photo and scheme of the experimental set-up of the bench-scale digesters are shown in Fig. 3. The feeding of the digesters was done manually 6 days a week. The feeding volume was $25-70 \mathrm{~mL} /$ day, resulting in hydraulic retention times (HRT) of 22-64 days. The digesters were shaken two to four times per day for mixing. The biogas production was measured daily. The water volume in the reception vessel is the volume of the biogas produced in the digester. Temperature and pressure correction have not been made because they balance with an error of less than $+5 \%$. The biogas composition was analyzed twice a week with a gas analyzer (SR2-DO Sewerin, Germany). 


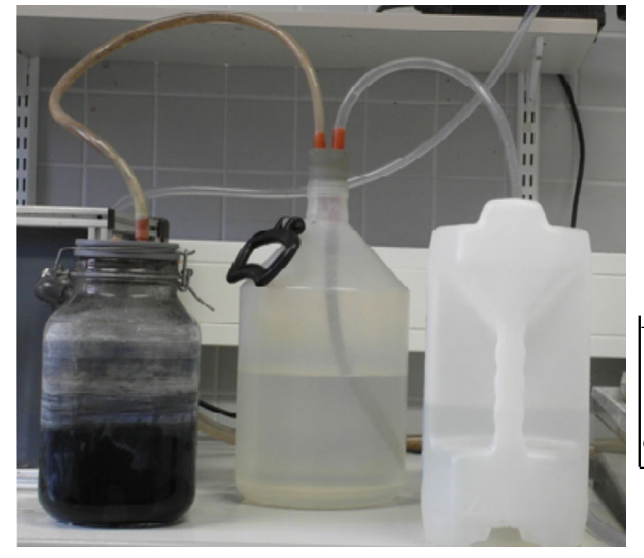

Fig. 3 Schemes and photos of bench-scale digesters

\section{Pilot-scale digesters}

Photos and schemes of the experimental set-up of the pilotscale anaerobic digester 1(PSAD1) are shown in Fig. 4. The PSAD1 has a working volume of $450 \mathrm{~L}$. The temperature was maintained at $39 \pm 1{ }^{\circ} \mathrm{C}$ by electric heating. The digester was mixed with a three-arm propeller-stirrer (Ø $500 \mathrm{~mm}) 24 \mathrm{~h} /$ day with $100 \mathrm{rpm}$. The feeding volume was 5.8-31.6 L/day, with HRT of 14-77 days. Daily feeding was done manually and micronutrients well mixed with the WW before the WW was fed to the digester. Biogas volume was measured with a wet gas meter (Ritter, Germany) and biogas composition with infrared detectors $\left(\mathrm{CH}_{4}\right.$ and $\mathrm{CO}_{2}$; SR2-DO Sewerin, Germany). Both were measured daily.

\section{Analytical methods}

In the experiments $\mathrm{pH}$, chemical oxygen demand (COD), total solids (TS), and volatile solids (VS) of the WW, biogas production and composition, $\mathrm{pH}$, TS, VS, volatile organic acids (VOA), and total inorganic carbon (TIC) of the digestate were regularly measured.

Fig. 4 Schemes and photos of pilot-scale anaerobic digesters

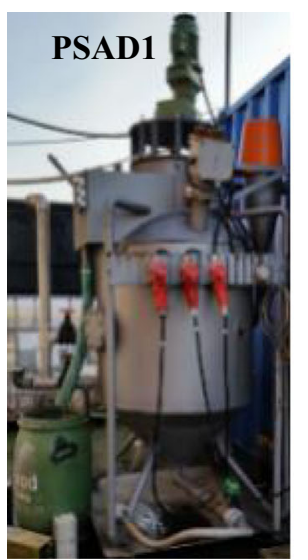

VOA and TIC were measured with the FOS/TAC 2000 (Pronova, Germany). The FOS/TAC 2000 is using the Nordmann titration method. The effluent of the digester was filtrated through a paper filter before the analysis. VOA is measured in grams of acetic acid per liter. TIC is a measurement of the buffer capacity, and the unit is grams of $\mathrm{CaCO}_{3}$ per liter.

The $\mathrm{pH}$ of the effluent of the digester was measured immediately after sampling, in order to avoid $\mathrm{pH}$ changes due to a loss (desorption) of carbon dioxide. The $\mathrm{pH}$ was measured using a $\mathrm{pH}$ meter (Microprocessor pocket-pH 325, WTW, Germany). The COD was analyzed with NANOCOLOR tube tests (Macherey-Nagel, Germany). The COD tests mimic the DIN ISO 15705 procedure. The samples were heated to $148{ }^{\circ} \mathrm{C}$ for 60 minutes and chromium-VI to chromium-III reduction was measured by absorption of 620-nm light NANOCOLOR photometer 500D (Macherey-Nagel, Germany). TS and VS are analyzed according to the German Guideline DIN ISO 11465. Trace elements in the wastewater and digestate were analyzed with ICP (inductively coupled plasma) at the laboratory of the ISF-Schaumann Bioenergy, Germany.

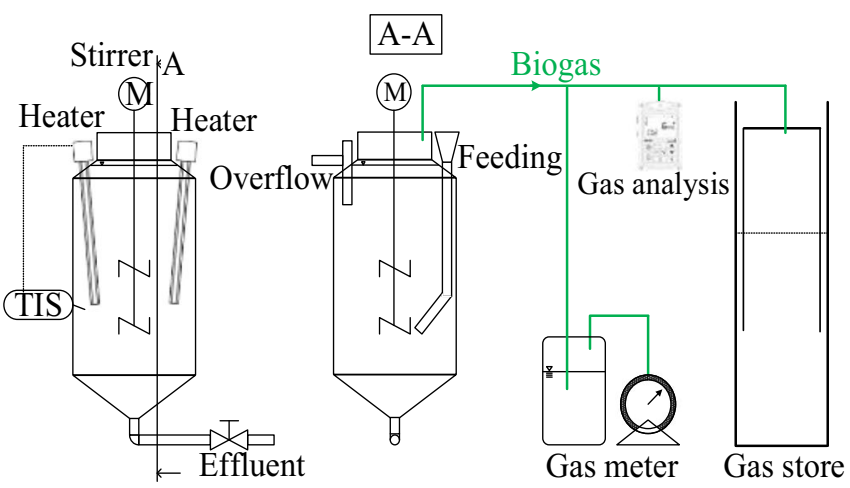




\section{Results and discussions}

\section{Bench-scale results}

In digester $\mathrm{B} 12$, a process deterioration was provoked by overloading (Fig. 5a, b). COD degradation increased steadily to $80 \%$ in digester B11 and stayed stable at that level with initial OLR being reduced after 6 days from 6.8 to $3.5 \mathrm{~kg}$ $\mathrm{COD} / \mathrm{m}^{3} /$ day. Digester $\mathrm{pH}$ was stable at 7.15 and VOA concentration remained less than $300 \mathrm{mg} / \mathrm{L}$. In digester B12 with a constant OLR of $6.8 \mathrm{~kg} \mathrm{COD} / \mathrm{m}^{3} /$ day, COD degradation never surpassed $40 \%$, VOA accumulated, and $\mathrm{pH}$ dropped. After 12 days of operation, COD degradation had decreased to less than $20 \%$, VOA increased up to $13 \mathrm{~g} / \mathrm{L}$, and $\mathrm{pH}$ dropped to 5.5. Li et al. (2013) point out that in anaerobic digestion of food waste, VOA should not surpass $750 \mathrm{mg} / \mathrm{L}$. When Li increased in his experiments, OLR from 6.7 to $8.4 \mathrm{~kg}$ $\mathrm{VS} / \mathrm{m}^{3} /$ day, the total VFA accumulated up to $8.4 \mathrm{~g} / \mathrm{L}$ and $\mathrm{pH}$ dropped to 6.2. These results are comparable to our findings. Adaption to a higher OLR than $3.5 \mathrm{~kg} / \mathrm{m}^{3} /$ day with a moderate stepwise increase in OLR and adequate adaption times can however not be excluded.

Digesters B9 and B10 were operated with OLR in the range of 2 to $4 \mathrm{~kg} \mathrm{COD} / \mathrm{m}^{3} /$ day. Without the addition of $\mathrm{NaHCO}_{3}$, digester alkalinity decreased constantly. $\mathrm{pH}$ followed this decrease but in a hardly measurable extent. Biogas production showed no indication unless critical conditions were surpassed. Then, biogas production showed a sharp decrease. VOA also did hardly react before critical conditions were surpassed. Then, the VOA concentration increased sharply and the anaerobic digestion was deteriorating. The decrease of alkalinity and $\mathrm{pH}$ and the effects of the decreasing biogas production and the VOA accumulation corresponded well with the simulation in the physicochemical model. Digester deteriorations are marked with red rings in Fig. $5 \mathrm{c}$, d. The recovery of the process required the addition of $\mathrm{NaHCO}_{3}$ and a stop of feeding. This has to be avoided in full-scale operation. These results confirmed well the calculations of the physicochemical model. Lebuhn et al. (2014) reported that in a fermenter operated with maize silage initial alkalinity also decreased. Alkalinity decreased from $10 \mathrm{~g} \mathrm{CaCO}_{3} / \mathrm{L}$ to $1 \mathrm{~g}$ $\mathrm{CaCO}_{3} / \mathrm{L}$ in the course of 1.5 years of operation. On the basis of their investigations, Burgstaler et al. (2011) came to the conclusion that $\mathrm{NaHCO}_{3}$ added to the fermenter stabilizes the $\mathrm{pH}$ and enhances the biogas yield in agricultural biogas plants in Germany.

\section{Pilot-scale results}

Figure 6 shows the pilot-scale digester PSAD1 performance. Initially, in phase 1, alkalinity in PSAD1 decreased from 4.5 to $1.7 \mathrm{~g} \mathrm{CaCO}_{3} / \mathrm{L}$ in the first 60 days. With alkalinity dropping
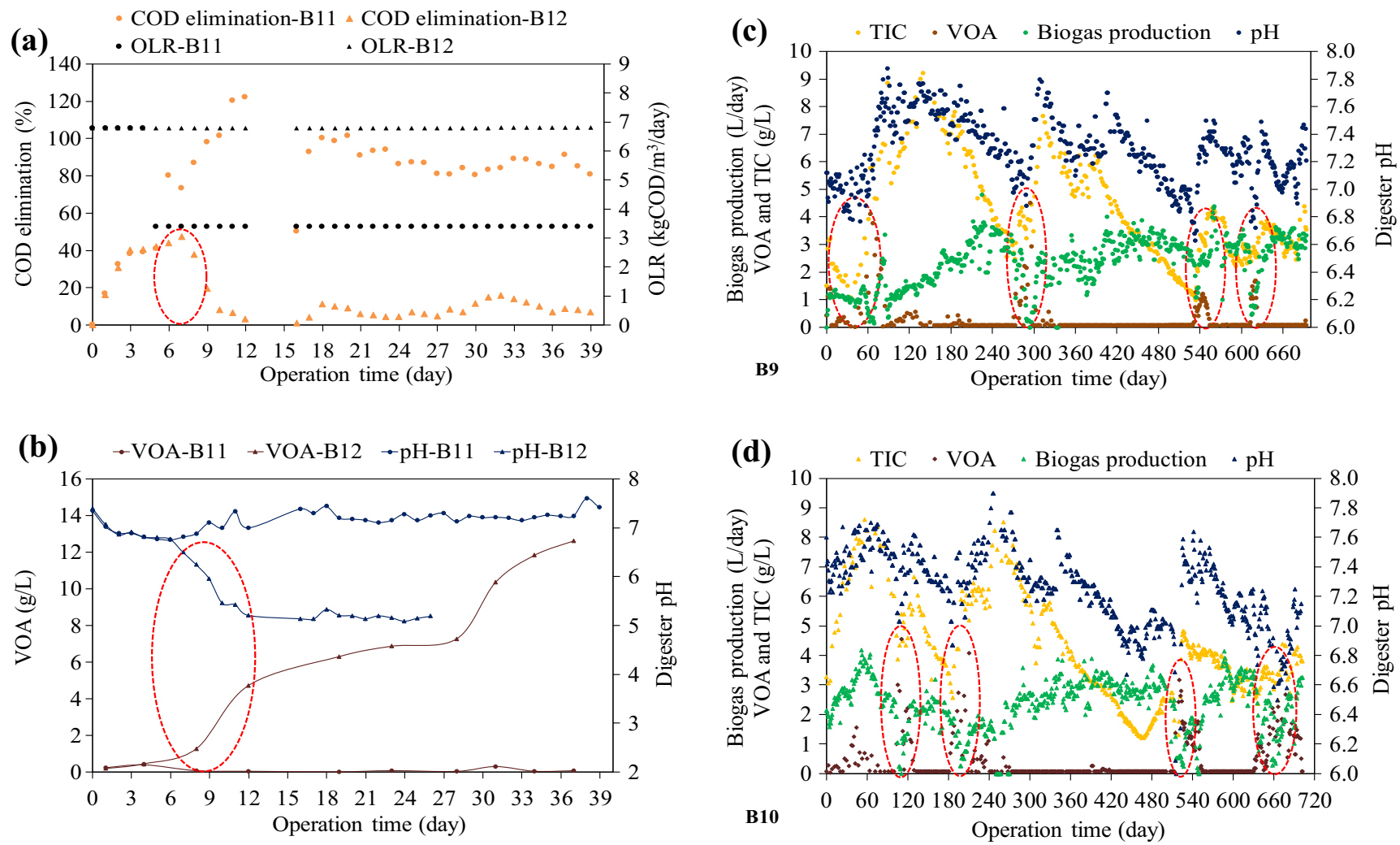

Fig. 5 Results of bench-scale experiments (B9-B12) with provoked digester imbalances (a-d) 
below $2 \mathrm{~g} \mathrm{CaCO}_{3} / \mathrm{L}$, VOA concentration increased to about $1.35 \mathrm{~g} / \mathrm{L}$, pH slightly decreased to 7.05 , and biogas production declined sharply. This is in good conformity with the benchscale digester results. $\mathrm{NaHCO}_{3}$ was added to increase alkalinity and $\mathrm{pH}$ and the process performance recovered. $2.4 \mathrm{~kg}$ $\mathrm{NaHCO}_{3} / \mathrm{m}^{3} \mathrm{WW}$ was then in phase 1 added in intervals for maintaining the alkalinity in the digester in the range 3-5 g $\mathrm{CaCO}_{3} / \mathrm{L}$ and the $\mathrm{pH}$ in the range of $7.1-7.3$ in accordance with the physicochemical model developed for this process. OLR was controlled at $1.8-2.5 \mathrm{~kg} \mathrm{COD} / \mathrm{m}^{3} /$ day. PSAD1 showed in this phase a stable COD elimination of approximately $88 \%$ and an average biogas production of $0.95 \mathrm{~m}^{3} / \mathrm{m}^{3}$ reactor/day and VOA was below $300 \mathrm{mg} / \mathrm{L}$. VOA/TIC ratio was below 0.1 indicating a stable digestion process (Drosg 2013). An imbalance of the digestion process (day 420) occurred due to WW with an extreme high grease and oil content causing foam formation. The high grease concentration in the WW caused a considerable formation of creamy foam, an increase in VOA, and a decrease in biogas production. However, the foam layer could be destroyed by vigorously shaking the foam in a bench-scale digester. The dispersed foam was degraded in the bench-scale digester. The lesson learned from this incident is that WW with extreme fat and oil concentrations should be transferred to a hazard tank and be added diluted to the WW. An intense mixing of the surface volume could safeguard a re-immersion of creamy foam and creamy foam in the effluent should be recycled into the influent.

In phase 2, OLR was stepwise increased from 2 to $5.2 \mathrm{~kg}$ $\mathrm{COD} / \mathrm{m}^{3} /$ day in order to optimize OLR and feasibility. The biogas production increased from day 490 to day 720 from $0.95-2.7 \mathrm{~m}^{3}$ biogas $/ \mathrm{m}^{3}$ digester volume/day rather parallel to the increase of the OLR from $2-4.5 \mathrm{~kg} \mathrm{COD} / \mathrm{m}^{3} /$ day. The following increase from OLR 4.5 to $5.2 \mathrm{~kg} \mathrm{COD} / \mathrm{m}^{3} /$ day on day 720 however lead to an accumulation of VOA from 0.1 to $1.9 \mathrm{~g} / \mathrm{L}$ and a drop of $\mathrm{pH}$ from 7.2 to 6.4 on day 754 . Then, the digester deteriorated, the feeding was stopped, and $\mathrm{NaHCO}_{3}$ was added in order to recover the digester again. The digesters recovered and operated well again with an OLR reduced to $4.5 \mathrm{~kg} \mathrm{COD} / \mathrm{m}^{3} /$ day. The learned lesson is that in full-scale OLR shall not exceed $3 \mathrm{~kg} \mathrm{COD} / \mathrm{m}^{3} /$ day in order to be on the safe side in case of troublesome WW with, i.e., high concentrations of fats and oils. During PSAD1 operation, the average $\mathrm{NaHCO}_{3}$ consumption was in the range of 2.17$3.15 \mathrm{~kg} \mathrm{NaHCO} / \mathrm{m}^{3}$ of WW in accordance with the physiochemical model.
Fig. 6 Results of pilot-scale experiments (PSAD1) with the stale digestion process $(\mathbf{a}, \mathbf{b})$

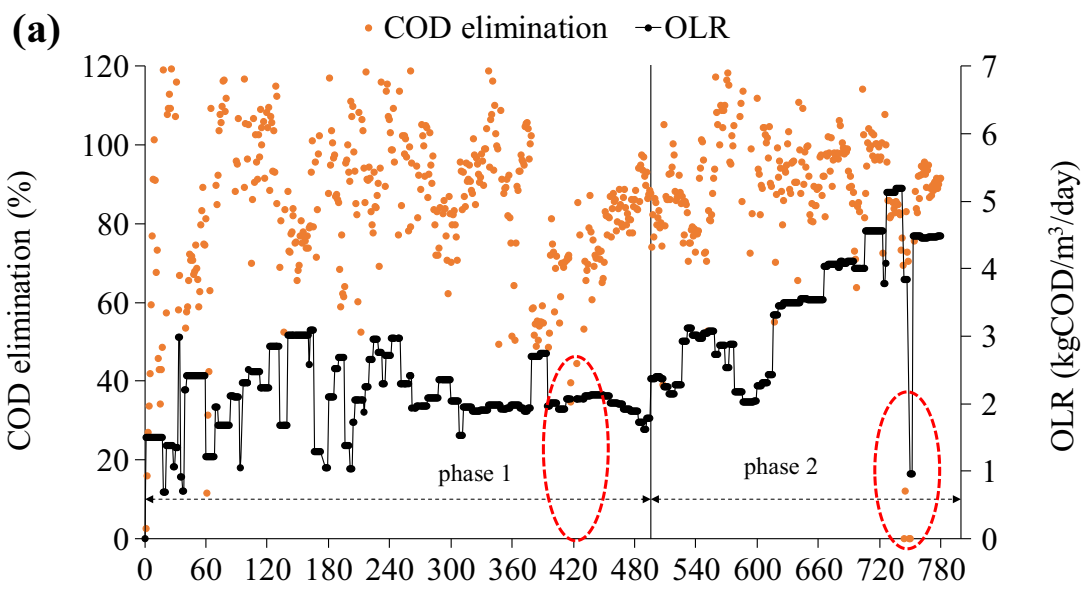

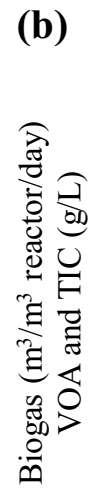

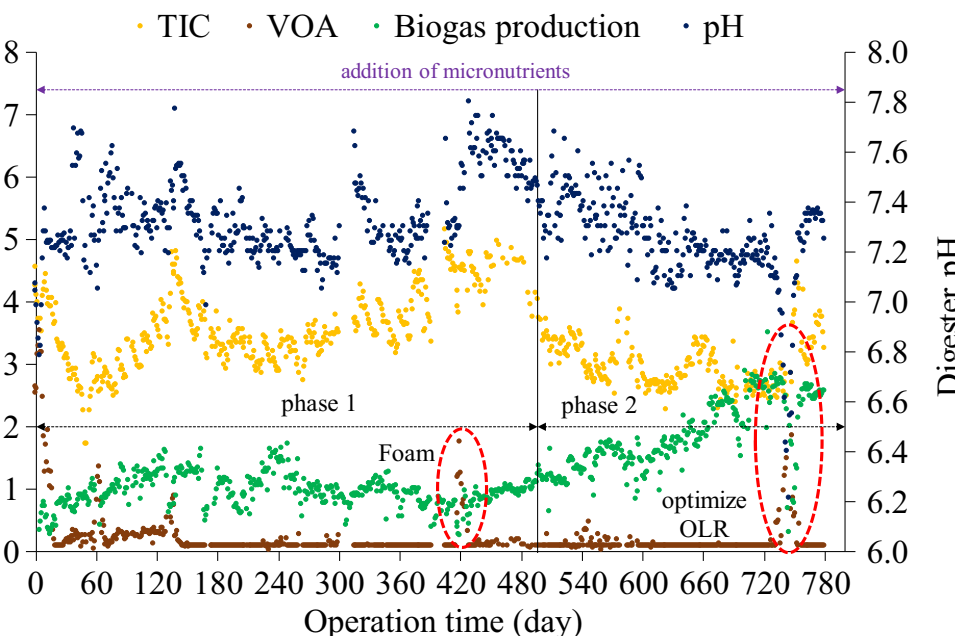




\section{Full-scale biogas plant performance}

Based on the collected experience, we designed a full-scale anaerobic treatment plant for TS-Clean site Fahrbinde that was built by ROTARIA Energie und Umwelttechnik, Rerik, Germany. The full-scale plant is automated for remote control and operation.

Figure 7 shows a photo of the biogas plant and a snapshot of the process control and digester performance data. In November 2017 , the $1200-\mathrm{m}^{3}$ biogas plant was commissioned. The $300-\mathrm{m}^{3}$ digested sludge from a cow manure biogas plant combined with the $700-\mathrm{m}^{3}$ digested sludge from the anaerobic sewage sludge digester of the WWTP Wismar was used to start up the full-scale biogas plant. During the startup phase, the feeding volume of the wastewater was slowly increased to $10 \mathrm{~m}^{3} /$ day in order to avoid an organic overloading.

The single-stage biogas plant is mixed intermittently and the temperature is controlled at $39 \pm 0.5^{\circ} \mathrm{C}$. In order to control the digester $\mathrm{pH}$ and to maintain the digester alkalinity (TIC), sodium hydrogen bicarbonate is added to the digester according to the digestion model. Also, micronutrients are added according to ISF-Schaumann-Bioenergy suggestions, in order to avoid a deficit of trace elements. Daily $\mathrm{pH}, \mathrm{VOA}$, and TIC of the biogas effluent are monitored in order to control the biogas plant performance.

The monitored data show that digester $\mathrm{pH}$ is stable at 7.4. The digester $\mathrm{pH}$ is still slightly higher than expected due to digested cow manure and sewage sludge with high ammonia nitrogen concentrations used as inoculum. VOA is below $300 \mathrm{mg} / \mathrm{L}$ and alkalinity is controlled not to fall below $3.5 \mathrm{~g}$ $\mathrm{CaCO}_{3} / \mathrm{L}$. The VOA/TIC ratio is well below 0.3 , indicating a stable anaerobic digestion process (Drosg 2013). The fullscale data show a $\mathrm{NaHCO}_{3}$ consumption of $1.4 \mathrm{~kg}$ $\mathrm{NaHCO}_{3} / \mathrm{m}^{3}$ of wastewater. The $\mathrm{NaHCO}_{3}$ consumption is lower than calculated with the model. This is probably still due to the cow manure and domestic sewage sludge used as inoculum.

The daily biogas production of $12 \mathrm{~m}^{3} \mathrm{WW}$ is approximately $800 \mathrm{~m}^{3}$, with $63 \% \mathrm{CH}_{4}$ in the dry biogas. The biogas yield is $68 \mathrm{~m}^{3} / \mathrm{m}^{3}$ of WW. Substitution of natural gas through biogas saves some $€ 8.500$ per month. Together with the savings in wastewater disposal, the return on investment is less than 5 years. The total solids in the biogas plant effluent are in the range $10-15 \mathrm{~g} / \mathrm{L}$. The effluent is flocculated and filtrated and the sludge is dewatered. The filtrate is discharged to the local WWTP Rastow. Eurofloc M-7 agent (Aquaplan, Germany) is used to floc the digester effluent (dosing $0.5 \%$ vol.). Flocculation, filtration, and sludge dewatering are realized in a screw filter press. Sludge separation and dewatering process are working stable. The consumption of the polymer is $36 \mathrm{~kg} /$ ton dry matter. The polymer dosage is $100 \mathrm{~L}$ solution $(0.5 \%) / \mathrm{m}^{3}$ digester effluent. The TS of the approximately 2.6 tons/week sludge cake is $25.4 \%$. The filtrate COD is $1-2 \mathrm{~g} / \mathrm{L}$, and the filtrate $\mathrm{pH}$ is 7.5 . The filtrate is discharged indirectly as it can be treated together with domestic wastewater with no adverse effects.
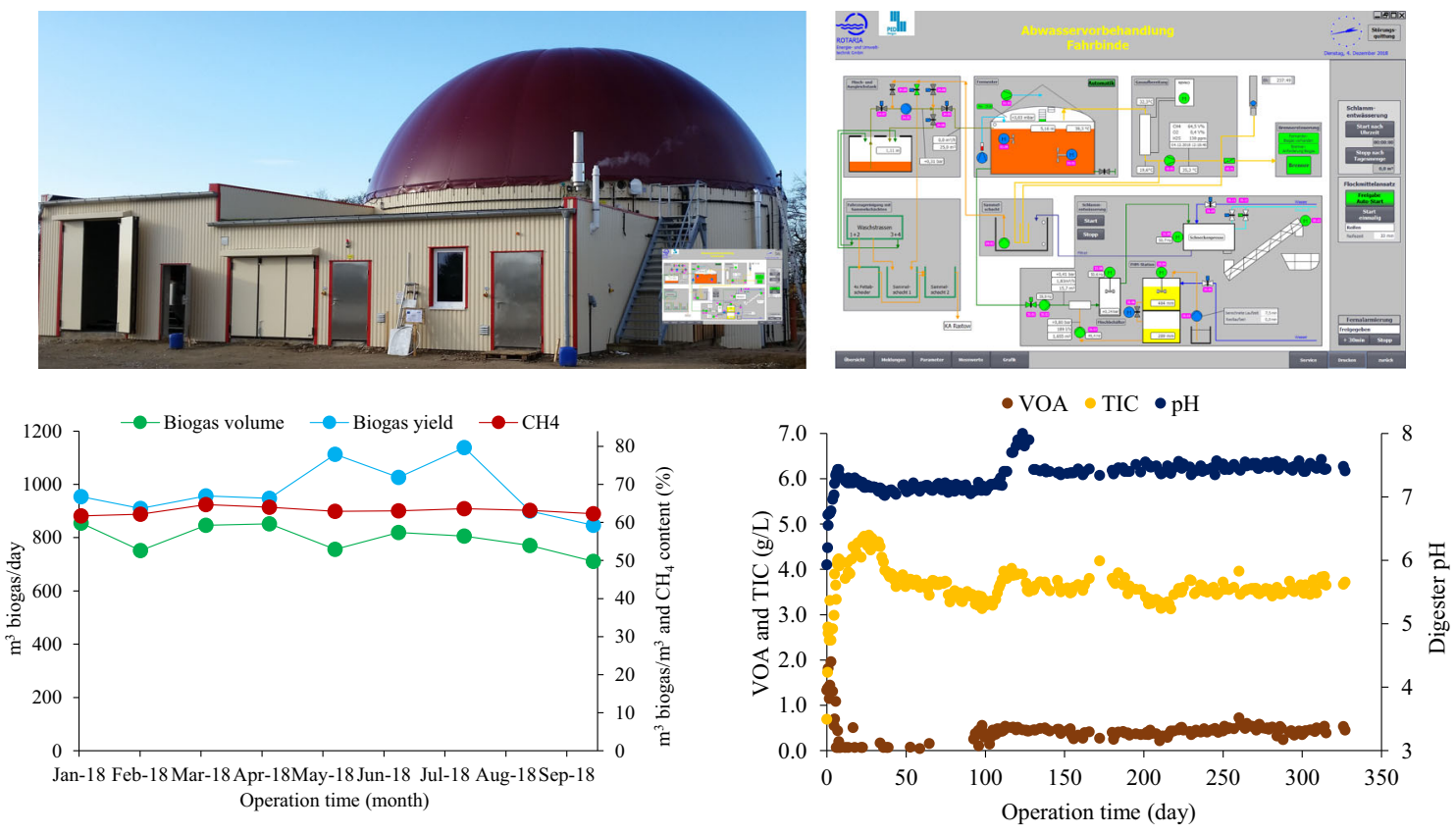

Fig. 7 Photo, control screen, and performance data of full-scale biogas plant in Fahrbinde 


\section{Conclusions}

Based on the experimental data and the model calculations, a $1200-\mathrm{m}^{3}$ biogas plant was built in TS-Clean cleaning station Fahrbinde for treating the highly polluted WW from the cleaning of tank cars. We learned that an equalization tank with the capacity of the WW of 1 week makes changes in strength and composition of the WW sufficiently smooth for anaerobic digestion, if OLR is not too high (OLR $<4 \mathrm{~kg} \mathrm{COD} / \mathrm{m}^{3} /$ day), HRT is long enough (HRT $>50$ days), and micronutrients are added. Sufficient alkalinity in the digester is essential for stabilizing the digestion process of highly polluted WW. Due to softened water used in the cleaning of the tanks, alkalinity in the digester decreases daily. The required addition of $\mathrm{NaHCO}_{3}$ for controlling $\mathrm{pH}=7.2-7.3$ and maintaining alkalinity around 3-4 $\mathrm{g} \mathrm{CaCO}_{3} / \mathrm{L}$ was calculated with a physicochemical model. The calculations of the model coincide well with the results of the digestion experiments and full-scale biogas plant operation. The biogas plant results can be used as reference data for an efficient anaerobic treatment of WW from food-processing industry. Based on these results, we are looking forward to build more biogas plants at car tank cleaning stations in Germany and in Europe. The biogas plant operators are trained for monitoring and controlling the digestion process based on the model calculation and personal experiences. For avoiding a VOA accumulation and an insufficient alkalinity, daily measurements of $\mathrm{pH}, \mathrm{VOA}$, and alkalinity are advised.

In order to recognize digestion process imbalances as early as possible and take appropriate action for avoiding a process deterioration, the physicochemical model needs to be expanded to study the influence of variations in strength and composition of the wastewater in combination with a digestion process inhibition due to overloading or inhibiting by toxic compounds in the wastewater causing an increase of VOA concentration.

Acknowledgements The authors would like to thank Mr. Jan Neumann for supplying the WW and Schaumann Bioenergy Company for the analysis of the trace elements. We would like to thank Mr. Wolfgang Schulz for the technical assistance in the experiments.

Funding information This $\mathrm{Ph}$. D research is supported by a grant from the German Academic Exchange Service-DAAD.

Open Access This article is distributed under the terms of the Creative Commons Attribution 4.0 International License (http:// creativecommons.org/licenses/by/4.0/), which permits unrestricted use, distribution, and reproduction in any medium, provided you give appropriate credit to the original author(s) and the source, provide a link to the Creative Commons license, and indicate if changes were made.

\section{References}

Bruce E. Rittmann, McCarty PL (2012) Process chemistry and microbiology. In: Environmental biotechnology: Principles and applications. McGraw Hill Professional, Access Engineering. https:// www.accessengineeringlibrary.com/browse/environmentalbi o t e chnology-principles-andapplications/ c9781260440591ch13lev1sec03. Accessed 10 Apr 2010

Burgstaler J, Wiedow D, Godlinski F, Kanswohl N (2011) Application of sodium bicarbonate in agricultural biogas plants. Landbauforschung Völkenrode 61:343-352

Chen S, Zhang J, Wang X (2015) Effects of alkalinity sources on the stability of anaerobic digestion from food waste Waste Management \& Research 33:1033-1040. https://oi.org/10.1177/ 0734242x15602965. Accessed 18 Apr 2018

Choong YY, Norli I, Abdullah AZ, Yhaya MF (2016) Impacts of trace element supplementation on the performance of anaerobic digestion process: a critical review. Bioresour Technol 209:369-379. https:// doi.org/10.1016/j.biortech.2016.03.028

Drosg B (2013) Technical brochure process monitoring. IEA Bioenergy. https://www.ieabioenergy.com/wp-content/uploads/2013/12/ Technical-Brochure-process_montoring.pdf. Accessed 4 Feb 2016

Facchin V, Cavinato C, Fatone F, Pavan P, Cecchi F, Bolzonella D (2013) Effect of trace element supplementation on the mesophilic anaerobic digestion of foodwaste in batch trials: the influence of inoculum origin. Biochem Eng J 70:71-77. https://doi.org/10.1016/j.bej. 2012.10.004

Gao $\mathrm{S}$ et al (2015) Evaluation the anaerobic digestion performance of solid residual kitchen waste by $\mathrm{NaHCO} 3$ buffering. Energy Convers Manag 93:166-174. https://doi.org/10.1016/j.enconman. 2015.01.010

Jang HM, Lee JW, Ha JH, Park JM (2013) Effects of organic loading rates on reactor performance and microbial community changes during thermophilic aerobic digestion process of high-strength food wastewater. Bioresour Technol 148:261-269. https://doi.org/10.1016/j. biortech.2013.08.090

Jeganathan J, Nakhla G, Bassi A (2006) Long-term performance of highrate anaerobic reactors for the treatment of oily wastewater. Environ Sci Technol 40:6466-6472. https://doi.org/10.1021/es061071m

Kleyböcker A, Liebrich M, Verstraete W, Kraume M, Würdemann H (2012) Early warning indicators for process failure due to organic overloading by rapeseed oil in one-stage continuously stirred tank reactor, sewage sludge and waste digesters. Bioresour Technol 123: 534-541. https://doi.org/10.1016/j.biortech.2012.07.089

Lebuhn M, Munk B, Effenberger M (2014) Agricultural biogas production in Germany - from practice to microbiology basics. Energy Sustainabil Soc 4:10. https://doi.org/10.1186/2192-0567-4-10

Li D, Sun Y, Guo Y, Yuan Z, Wang Y, Zhen F (2013) Continuous anaerobic digestion of food waste and design of digester with lipid removal. Environ Technol 34:2135-2143. https://doi.org/10.1080/ 09593330.2013.808237

Li L, He Q, Wei Y, He Q, Peng X (2014) Early warning indicators for monitoring the process failure of anaerobic digestion system of food waste. Bioresour Technol 171:491-494. https://doi.org/10.1016/j. biortech.2014.08.089

Mao C, Feng Y, Wang X, Ren G (2015) Review on research achievements of biogas from anaerobic digestion. Renew Sust Energ Rev 45:540-555. https://doi.org/10.1016/j.rser.2015.02.032

Nagao $\mathrm{N}$ et al (2012) Maximum organic loading rate for the single-stage wet anaerobic digestion of food waste. Bioresour Technol 118:210 218. https://doi.org/10.1016/j.biortech.2012.05.045

Philipowski D-IH-D (2016) ENFIT International Tank-Cleaning Association Food and Feed Safety in the Supply Chain Food and Feed Compliance FECC Seminar

Philipowski HD (2008) Cleaning technology: ein praktisches Handbuch für Investoren, Planer, Betreiber, Tankreiniger und FassRekonditionierer/ [Hrsg.: Hans-Dieter Philipowski]. Storck,

Röhr U, Müßig M (2006) Abschlussbericht: Entwicklung und Erprobung eines Verfahrens zur weitergehenden Reinigung von Abwässern aus der Tankwageninnenreinigung am Beispiel der Spedition Anhalt Deutsche Bundesstiftung Umwelt, Osnabrück. 
https://www.dbu.de/OPAC/ab/DBUAbschlussbericht-AZ-17863. pdf. Accessed 13 Mar 2018

Rudolf KU, Köppke KE, Korbach J (1995) Stand der Abwassertechnik in verschiedenen Branchen. vol v. 1. Umweltbundesamt 1995, Texte 72/95. http://www.dwa.de/dwa/sitemapping.nsf/literaturvorschau? openform\&bestandsnr=13026. Accessed 13 July 2017

Schattauer A, Abdoun E, Weiland P, Plöchl M, Heiermann M (2011) Abundance of trace elements in demonstration biogas plants. Biosyst Eng 108:57-65. https://doi.org/10.1016/j.biosystemseng. 2010.10 .010

Silva AJ, Pozzi E, Foresti E, Zaiat M (2015) The influence of the buffering capacity on the production of organic acids and alcohols from wastewater in anaerobic reactor. Appl Biochem Biotechnol 175: 2258-2265. https://doi.org/10.1007/s12010-014-1424-y

Xu F, Li Y, Ge X, Yang L, Li Y (2018) Anaerobic digestion of food waste - challenges and opportunities. Bioresour Technol 247:1047-1058. https://doi.org/10.1016/j.biortech.2017.09.020

Zhang J, Wang Q, Zheng P, Wang Y (2014) Anaerobic digestion of food waste stabilized by lime mud from papermaking process. Bioresour Technol 170:270-277. https://doi.org/10.1016/j.biortech.2014.08.003

Zhang L, Jahng D (2012) Long-term anaerobic digestion of food waste stabilized by trace elements. Waste Manag 32:1509-1515. https:// doi.org/10.1016/j.wasman.2012.03.015 